\title{
Molecular constituents of the replication apparatus in the plasmodium of Physarum polycephalum : identification by photoaffinity labelling
}

\author{
Sabine Doerhoefer, ${ }^{1}$ Svetlana Khodyreva, ${ }^{2}$ Igor V. Safronov, ${ }^{2}$ \\ Wjatschesslaw A. Wlassoff, ${ }^{3}$ Rushid Anarbaev, ${ }^{2}$ Olga I. Lavrik ${ }^{2}$ \\ and Eggehard Holler ${ }^{\top}$
}

Author for correspondence: Eggehard Holler. Tel: +49941943 3030. Fax: +499419432813. e-mail: Eggehard.Holler@biologie.uni-regensburg.de

1 Institut für Biophysik und physikalische Biochemie der Universität, D-93040 Regensburg, Germany

2,3 Novosibirsk Institute of Bioorganic Chemistry ${ }^{2}$ and Institute of Cytology and Genetics ${ }^{3}$, Siberian Division of the Russian Academy of Sciences, 630090 Novosibirsk, Russia

\begin{abstract}
The plasmodium of Physarum polycephalum has long been considered a model system for syncytically growing cells, but important details of the DNA replication apparatus, such as the DNA polymerase $\varepsilon$ and other replication factors, have not been detected. In this study, a new variation of photoaffinity labelling and immunoblotting was used to detect DNA polymerases and other factors in nuclear extracts of $P$. polycaphalum. Proteins were specifically cross-linked with photoreactive arylazido-dCMP residues incorporated during extension of template-primer DNA. The DNA synthesized in situ was ${ }^{32} \mathrm{P}$ labelled. After nucleolytic removal of protruding DNA, the proteins were separated by SDS-gel electrophoresis, electroblotted on membranes and subjected to autoradiography. The $\alpha, \delta, \varepsilon$ and $\beta$-like DNA polymerases were labelled, as were histones and replication-factor-like proteins. Cytoplasmic extracts were devoid of these species. Abundant proliferating-cell nuclear antigen and replication protein A large subunit were labelled and found to be of unusual mass. A number of subunits of purified DNA polymerase holoenzymes were labelled. In contrast, only the DNA-polymerizing subunits could be labelled in nuclear extracts. Higher-order complexes in the nuclear extract may make subunits inaccessible to photo-cross-linking. Complex formation is promoted by $\beta$-poly(L-malate), a plasmodium-specific putative storage and carrier molecule that supports DNA replication in the synchronized nuclei. Percoll, a polyvinylpyrrolidone-coated colloidal silica, partially disrupted these complexes. A $200 \mathrm{kDa}$ fragment of DNA polymerase $\varepsilon$ and a $135 \mathrm{kDa} \beta$-like DNA polymerase did not participate in the complexes, suggesting functions unlike those of the other polymerases. DNA polymerase molecules were intact during proliferation of plasmodia, but were nicked before their clearance from the nuclei at growth arrest.
\end{abstract}

Keywords: DNA replication, syncytium, protist, photoaffinity labelling, cross-linking

\section{INTRODUCTION}

Eukaryotic nucleic acid replication has been intensively investigated in a series of model systems such as yeast, mouse and human cells, and it has been assumed that the constituents and mechanisms of the replicating systems are largely conserved among eukarya, and also that they share functional similarities with those of bacteria and probably archaea (for a recent review see Hindges \& Hübscher, 1997). It is not clear what variations might 
exist for organisms which emerged early in evolution or have an unusual cellular organization. Physarum polycephalum meets both these criteria. Previous results placed this slime mould among protists (Margulis \& Schwartz, 1982; Johansen et al., 1988; Cavalier-Smith, 1993; Woese, 1994), while recent findings suggested its evolution among plants, fungi and animals (Baldauf \& Doolittle, 1997).

Nuclei of plasmodial $P$. polycephalum divide with high synchrony without passing through cytokinesis, giving rise to a large multinuclear syncytium (for a review see Burland et al., 1993). To gain insight into evolutionary variability and synchrony maintenance, we began to characterize the replication apparatus of $P$. polycephalum. DNA polymerase $\alpha$-primase complex (140 kDa polymerizing subunit, two primase subunits of 53 and $58 \mathrm{kDa}$, and a $82 \mathrm{kDa}$ polypeptide) (Weber et al., 1988; Achhammer et al., 1992; Angerer \& Holler, 1995), DNA polymerase $\delta(125 \mathrm{kDa})$ and PCNA $(35 \mathrm{kDa})$ (Achhammer et al., 1995) have been identified and characterized. The DNA polymerase $\alpha 140 \mathrm{kDa}$ subunit was proteolytically unstable, forming an inactive $110 \mathrm{kDa}$ fragment (Weber et al., 1988). The polymerase was found to differ in several respects from polymerases of yeasts and higher eukaryotes (Achhammer et al., 1995).

In search of a molecular device that could account for the synchrony of nuclear division, we have identified an unusual polymer, $\beta$-poly (L-malate) (PMLA) (Fischer et al., 1989). This polyanion is specifically synthesized in plasmodia but not in uninuclear cell forms of $P$. polycephalum. Its mode of action has been tentatively attributed to transport and storage of histones, DNA polymerases $\alpha$ and $\delta$, and other nuclear proteins in DNA replication (Fischer et al., 1989; Holler et al., 1992b; Achhammer et al., 1995; Angerer \& Holler, 1995). $\beta$-like DNA polymerase, which is probably not active in DNA replication, does not bind to PMLA. In the complexes, the activities of DNA polymerases are reversibly inhibited. The reaction is highly myxomycete-specific since DNA polymerases of other eukarya or bacteria are not inhibited (Fischer et al., 1989; Holler et al., 1992b, and unpublished data).

Our investigation was intended to gain further insight into the replication apparatus of $P$. polycephalum and to compare it with the systems of higher eukaryotes. We wanted to validate and expand the knowledge on the role of PMLA. We concentrated on identifying the still missing main players DNA polymerase $\varepsilon$ and replication factors. A suitable method for recognizing such proteins was the photoaffinity technique designed to label enzymically active DNA polymerases (Doronin et al., 1992; Lavrik \& Potapova, 1994; Safronov et al., 1997) and replication protein A (RP-A) (Lavrik et al., 1998) in purified systems. By introducing highly efficient photocross-linkers and an optimized protocol, labelling was performed in cell extracts. $\left[\alpha^{32} \mathrm{P}\right] \mathrm{dNTP}$ and a photoreactive arylazido derivative of $\mathrm{dCTP}$ were incorporated into nuclease-activated salmon testis DNA simul- taneously. The nascent DNA was cross-linked by irradiation to DNA-bound proteins. After SDS-PAGE and electroblotting, DNA polymerase $\alpha, \delta, \varepsilon$, PCNA, RP$A$ and replication factor $C$ (RF-C) proteins were identified by autoradiography and immunostaining. The technique allowed us to purify DNA polymerase $\varepsilon$ and to observe effects with PMLA and oligophosphate dinucleotides. The function of PMLA was evident from the results of labelling. It integrated DNA polymerases into higher-order complexes. At the beginning of the starvation-induced switch to the non-replicative phase of the life cycle, the polymerase components of the complexes were proteolytically nicked before they disappeared from the nuclei.

\section{METHODS}

Materials. Benzonase grade Il $\left(25\right.$ units $\left.\mu^{-1}\right)$ was purchased from Merck. $\left[\alpha^{-32} \mathrm{P}\right] \mathrm{dNTPs}\left(3000 \mathrm{Ci} \mathrm{mmol}{ }^{-1} ; 1 \mathrm{Ci}=3 \cdot 7 \times\right.$ $10^{10} \mathrm{~Bq}$ ) and molecular mass markers were purchased from Amersham. $T_{4}$ polynucleotide kinase was purchased from Life Technologies. DNA polymerase I from Escherichia coli was purchased from Boehringer Mannheim. Purified P. polycephalum DNA polymerase $\alpha$ was the phosphocellulose fraction according to Weber et al. (1988) and Achhammer et al. (1992). P. polycephalum DNA polymerase $\delta$ was purified as described by Achhammer et al. (1995). The enzymes were stored at $-70^{\circ} \mathrm{C}$ in the presence of $50 \%(\mathrm{v} / \mathrm{v})$ glycerol, $50 \mathrm{mM}$ Tris/ $\mathrm{HCl} \mathrm{pH} 7 \cdot 5,1 \mathrm{mM}$ EDTA and $1 \mathrm{mM}$ 2-mercaptoethanol. All other reagents were of analytical grade and were purchased from Merck. Rabbit antiserum against $P$. polycephalum DNA polymerases $\alpha$ and $\varepsilon$ (both as holoenzymes) and rabbit antiserum against peptides of $P$. polycephalum DNA polymerase $\delta$ have been described (Achhammer et al., 1992, 1995). Chicken antiserum against human PCNA was a gift from Dr B. Stillman (Cold Spring Harbor, USA). Rabbit antiserum against human RP-A, $70 \mathrm{kDa}$ subunit, was a gift from Dr K. Weisshart (Jena, Germany). Antiserum against yeast replication factor C4 (RF-C4) was a gift from Dr P. M. J. Burgers (St Louis, USA). Peroxidasecoupled anti-rabbit IgG and anti-chicken IgY antibodies were purchased from Pierce.

Photoreactive analogues of nucleotide triphosphates. The photoreactive nucleotides exo-N-[2-(5-azido-2-nitrobenzamido)ethyl]deoxycytidine- $5^{\prime}$-triphosphate (ANBdCTP) and exo- $N$-[([[(4-azido-2,3,5,6-tetrafluorobenzylidene)hydrazino ] carbonyl]butyl)carbonyl]deoxycytidine-5' $5^{\prime}$ triphosphate (AFBdCTP) were synthesized as described previously (Safronov $e t$ al., 1997). Their structures are shown in Fig. 1. Absorbance maxima were at $303 \mathrm{~nm}\left(9000 \mathrm{M}^{-1} \mathrm{~cm}^{-1}\right)$ for AFBdCTP and at $320 \mathrm{~nm}\left(8000 \mathrm{M}^{-1} \mathrm{~cm}^{-1}\right)$ for ANBdCTP. A cut-off filter $(0 \cdot 6$ absorbance units at $310 \mathrm{~nm}$ and complete cut-off at $295 \mathrm{~nm}$ ) was used during photo-cross-linking to protect the samples against far-UV light. The light source was an Osram XBO $150 \mathrm{~W}(7.5 \mathrm{~A})$ high-pressure xenon lamp. The distance between the source and the sample was $15 \mathrm{~cm}$. The nucleotide analogues were photo-inactivated with half-lives of $1 \mathrm{~min}$ (AFBdCTP) and $3 \mathrm{~min}$ (ANBdCTP); they were superior to previously synthesized reagents and to commercially available nucleotides such as BrdUTP in their high cross-linking yields (5-7\% of the photoreactive DNA cross-linked with bound proteins) and their rapid photoinactivation (Safronov et al., 1997).

Template-primers. Activated salmon testis DNA was prepared 

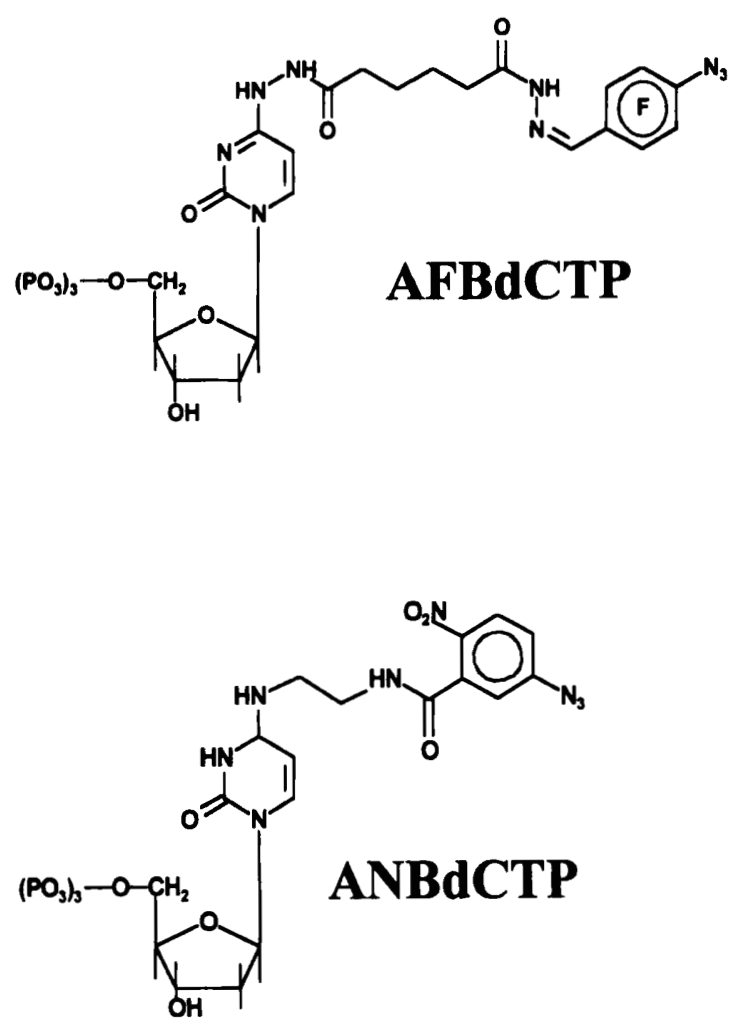

Fig. 1. Structures of AFBdCTP and ANBdCTP.

according to Holler et al. (1987). Synthetic 16-mer primer $5^{\prime}$ GTTTTCCCAGTCACGA 3' was annealed to a synthetic 26mer template $3^{\prime}$ CAAAAGGGTCAGTGCTGTTAACCTAC $5^{\prime}$ or to M13mp18 DNA $3^{\prime}$....CAAAAGGGTCAGTGCTGCAACATTTTGCT...5' (annealed bases underlined). The primer was $5^{\prime}$-end labelled with $\left[\gamma^{32} \mathrm{P}\right] \mathrm{ATP}$ as described by Sambrook et al. (1989), and was separated from excess reactants on NENSORB-20 (DuPont). Other synthetic template-primers were poly $(\mathrm{rA}) / \mathrm{p}(\mathrm{dT})_{12-18}(10 / 1)$, poly $(\mathrm{dA}) /$ $\mathrm{p}(\mathrm{dT})_{12-18}(10 / 1)$ and poly $(\mathrm{dT}) / \mathrm{p}(\mathrm{rA})_{10}(20 / 1)$, prepared according to Achhammer et al. (1995).

DNA polymerases. DNA polymerase $\varepsilon$ was separated from the other DNA polymerases on phosphocellulose (Achhammer et al., 1995); it eluted with $410 \mathrm{mM} \mathrm{KCl}$ close to the position for DNA polymerase $\alpha(590 \mathrm{mM} \mathrm{KCl})$. Purification was continued over hydroxyapatite (elution with 180-200 mM KCl), ssDNA cellulose $(340 \mathrm{mM} \mathrm{KCl})$, and MonoQ $(270 \mathrm{mM} \mathrm{KCl})$. At all stages of the purification the polymerase was identified by photolabelling and by its molecular mass of $230 \mathrm{kDa}$. After chromatography on MonoQ, the preparation had high specific activity but contained mainly proteolytically nicked polymerase. The purified polymerase was stored in $50 \%(\mathrm{v} / \mathrm{v})$ glycerol buffer at $-70^{\circ} \mathrm{C}$.

Nuclear extract. Microplasmodia of $P$. polycephalum strain $\mathrm{M}_{3}$ CVII or $\mathrm{M}_{3}$ CVIII (ATCC 96951) were grown for 2-4 d $(0.3 \mathrm{~g}$ wet inoculum) in $100 \mathrm{ml}$ medium $(500 \mathrm{ml}$ indented Erlenmeyer flasks) according to Daniel \& Baldwin (1964). Cells were disrupted with $8-10$ strokes in a Dounce homogenizer at $4{ }^{\circ} \mathrm{C}$ in 1 vol. disruption buffer, containing $15 \mathrm{mM}$ Tris $/ \mathrm{HCl}$ pH 7.5, $5 \mathrm{mM}$ EGTA, $0.5 \mathrm{mM} \mathrm{CaCl}, 15 \mathrm{mM}$ $\mathrm{MgCl}_{2}, 500 \mathrm{mM}$ hexylene glycol, $10 \%$ (v/v) dextran, $14 \mathrm{mM}$ 2-mercaptoethanol, $5 \mathrm{mM}$ sodium bisulfite, $0.2 \mathrm{mM}$ PMSF,
$1 \mathrm{mM}$ benzamidine (Sigma), $1 \mu \mathrm{M}$ pepstatin A (Merck), $10 \mu \mathrm{M}$ leupeptin (Sigma), $1 \mathrm{mg}$ aprotinin (Merck) $\mathrm{ml}^{-1}, 10 \mu \mathrm{l}$ tosyl-Llysine chloromethyl ketone (Calbiochem), $100 \mu \mathrm{M}$ Pefabloc SC (Merck), and $2 \mu \mathrm{g} \mathrm{E} 64$ (Boehringer Mannheim) $\mathrm{ml}^{-1}$. Nuclei were either pelleted directly from lysed plasmodia (Schmidt et al., 1996) or purified using a $25 \%$ Percoll (v/v) gradient in disruption buffer as described by Angerer $\&$ Holler (1995). The nuclear pellet $\left(3 \times 10^{8}\right.$ leakproof nuclei) was

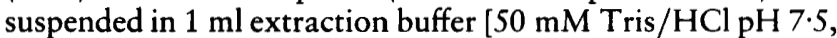
$20 \mathrm{mM} \mathrm{MgCl}_{2}, 0.5 \%$ (v/v) Triton X-100, $20 \%$ (v/v) glycerol, $1 \mathrm{mM} 2$-mercaptoethanol and $50 \mathrm{mM} \mathrm{KCl}$, incubated for $10 \mathrm{~min}$ on ice and pelleted at $700 \mathrm{~g}$. The supernatant was assayed by the photoaffinity technique. The cytoplasmic fraction, and in washing experiments the supernatant of the nuclear pellet (before extraction), were also subjected to photoaffinity labelling.

DNA polymerase activity assays. The activities of DNA polymerases were routinely standardized by assaying acidprecipitable radioactivity incorporated into DNA synthesized from $\left[\alpha-{ }^{32} \mathrm{P}\right] \mathrm{dTTP}$ as substrate. For DNA polymerase $\alpha$, DNase-I-activated salmon testis DNA was used as templateprimer (Holler et al., 1987), and for DNA polymerases $\delta$ and $\varepsilon$, poly $(\mathrm{dA}) / \mathrm{p}(\mathrm{dT})_{12-18}$ (Achhammer et al., 1995). One unit of enzyme activity represents the incorporation of $1 \mathrm{nmol}$ bases during $1 \mathrm{~h}$ at $37^{\circ} \mathrm{C}$ in the standard assay.

Labelling of DNA polymerases and DNA-interacting proteins. AFBdCTP was used in most of the experiments because it had a higher labelling efficiency than ANBdCTP. Samples were labelled in a solution $(20 \mu \mathrm{l})$ containing $0.05-0.5$ units DNA polymerase, $3-5 \mu \mathrm{M}\left[\alpha^{-32} \mathrm{P}\right] \mathrm{dATP}\left(3-3000 \mathrm{Ci} \mathrm{mmol}^{-1}\right), 50-$ $100 \mu \mathrm{M}$ AFBdCTP, $50 \mathrm{mM}$ MOPS buffer (pH 7.5), $50 \mathrm{mM}$ $\mathrm{KCl}, 10 \mathrm{mM} \mathrm{MgCl}, 3 \mathrm{mM}$ EDTA and occasionally $33 \mu \mathrm{M}$ each of dGTP and dTTP. Five micrograms of activated salmon testis DNA was used as template-primer in routine experiments and in a few cases, $50-100 \mathrm{nM}$ synthetic $26-\mathrm{mer}$ template/16-mer primer oligonucleotides, 50-100 nM M13mp18 DNA/16-mer primer, or $5 \mu \mathrm{g}$ primed synthetic homopolymers $\mathrm{ml}^{-1}$. The standard labelling mixture for nuclear extracts contained the above assay components, $33 \mu \mathrm{M}$ each of dGTP and dTTP, occasionally $0.2 \mathrm{mM}$ spermine. $\mathrm{HCl}$ (to mask the endogenous inhibitor PMLA), $0 \cdot 1 \mu \mathrm{M}\left[\alpha^{32} \mathrm{P}\right] \mathrm{dATP}$ (3000 $\mathrm{Ci} \mathrm{mmol}{ }^{-1}$ ), $125 \mu \mathrm{M}$ AFBdCTP (or ANBdCTP) and 5-10 $\mu \mathrm{l}$ nuclear extract. Polymerization proceeded for $10 \mathrm{~min}$ at $37^{\circ} \mathrm{C}$ in the strict absence of light (black cups). An aliquot was then irradiated for $2 \mathrm{~min}$ (for ANBdCTP, $5 \mathrm{~min}$ ). To remove free DNA and DNA ends protruding from crosslinked complexes with proteins, the products were digested with benzonase ( 25 units per sample) for $10-15 \mathrm{~min}$ at $37^{\circ} \mathrm{C}$. When $5^{\prime}-{ }^{32} \mathrm{P}$-labelled primer was used, digestion was omitted. For catalytically competent labelling, the mixture of DNA polymerase and AFBdCTP were irradiated for $2 \mathrm{~min}$; this photo-cross-linked the photoreactive nucleotide to the polymerase and quantitatively photoinactivated excess reagent. Polymerase-catalysed ligation of the cross-linked dCTP analogue with $55 \mathrm{nM}$ template $/ 5^{\prime}-\left[{ }^{32} \mathrm{P}\right] 16-$ mer primer was allowed for $40 \mathrm{~min}$ at $37^{\circ} \mathrm{C}$. Samples were heated for $3 \mathrm{~min}$ with Laemmli (1970) buffer and submitted to denaturing SDSPAGE (5-15\% acrylamide), electroblotting on Millipore Immobilon membranes (Towbin et al., 1979), and autoradiography for $5-7 \mathrm{~d}$ (Kodak X-OMAT LS at $-70^{\circ} \mathrm{C}$ ). The blotted proteins were stained with immune reagents according to Towbin et al. (1979) and occasionally visualized by enhanced chemiluminiscence (ECL, Amersham). Molecular masses (standard deviation $\pm 3 \%$ of the mean value, $n>7$ ) were determined by comparison with high and low molecular mass marker proteins from Sigma. We routinely included $E$. 
coli DNA polymerase I in the photoaffinity reaction mixture as a positive control and omitted the photoreactive nucleotide or irradiation as a negative control.

Primer extension with AFBdCTP or ANBdCTP was carried out in 4.5-10 $\mu \mathrm{l}$ reaction mixture containing $0.005-0.02$ units of highly purified $P$. polycephalum DNA polymerase $\alpha$, $0 \cdot 01-0 \cdot 1 \mu \mathrm{M}$ synthetic $5^{\prime}-\left[{ }^{32} \mathrm{P}\right]$ primer and template (synthetic 26-mer or M13mp18 DNA), indicated concentrations of photoreactive nucleotide, $50 \mathrm{mM}$ Tris $/ \mathrm{HCl} \mathrm{pH} \mathrm{7.5,50} \mathrm{mM}$ $\mathrm{KCl}, 10 \mathrm{mM} \mathrm{MgCl}, 0.3 \mathrm{mM}$ EDTA and $0.01 \mathrm{mM}$ 2-dithioerythritol. Reaction was allowed for $15 \mathrm{~min}$ at $37^{\circ} \mathrm{C}$. In some assays natural dNTPs were added, and the incubation was continued for $15 \mathrm{~min}$. To terminate the reaction, $5 \mu \mathrm{l}$ stop solution $[80 \%(\mathrm{v} / \mathrm{v})$ aqueous formamide, $50 \mathrm{mM}$ Tris/boric acid buffer $\mathrm{pH} 8 \cdot 3,1 \mathrm{mM}$ EDTA and $0.1 \%$ bromophenol blue] was added. Samples $(5-10 \mu \mathrm{l})$ were analysed on $20 \%$ polyacrylamide-urea gels (Sambrook et al., 1989).

\section{RESULTS AND DISCUSSION}

\section{Incorporation of photoreactive nucleotides into DNA during primer extension}

Incorporating the dCTP analogues into DNA during primer extension catalysed by $P$. polycephalum DNA polymerase $\alpha$ was confirmed to give a single product at low concentrations of AFBdCTP (Fig. 2a, lane 4, band d). Incorporation was inhibited when dCTP was included in the polymerization mixture (Fig. 2a, lanes $5-8$ ), resulting in the extension of primer (band a) by a single dCMP (band $b$ ). The inhibition was complete for $50 \mu \mathrm{M} \mathrm{dCTP}$ (Fig. 2a, lanes 6 and 8). This suggested that the dCTP derivatives represented functional analogues of dCTP. The electrophoretic mobility of the product $d$ in Fig. 2(a) was less than that of products having dCMP (Fig. 2a, band b) or dCMP together with dAMP incorporated (Fig. 2a, band c) and was in agreement with the bulkiness of the photoreactive nucleotide. An additional product, band $\mathrm{e}$, was seen at elevated concentrations of AFBdCTP after 1 min (Fig. 2a, lane 5) and especially after prolonged polymerization (Fig. 2b). Band e represents an incorporation of AFBdCTP opposite to $\mathrm{dT}$ and next to $\mathrm{dG}$ of the 26-mer template. Band $\mathrm{f}$ in Fig. 2(c), lane 2, represents an incorporation opposite to $\mathrm{dC}$ of the M13mp18 template. Other results indicated an incorporation in the position of dT. Primer extension with ANBdCTP showed a comparably higher degree of fidelity (Fig. 2c, lanes 1 and 3), corresponding to a single product in band $g$. Misincorporation became complicated when dGTP or dATP was also included into the polymerization mixture, as shown by the emergence of several products in Fig. 2(c), lanes 3 and 4, and Fig. 2(d), lanes 2 and 3. The observed low level of fidelity reflected the general tendency of a polymerization catalysed by DNA polymerase $\alpha$. Full-length primer extension was probed in the presence of nucleotides dATP, dGTP, dTTP and the photoreactive dCTP analogue. Products $h$ and $i$ in Fig. 2(e), lanes 3 and 4, migrated close to product $\mathrm{k}$ in the presence of the four natural dNTPs (Fig. 2e, lane 5), suggesting a nearly fulllength polymerization. In summary, the results indicated the incorporation of AFBdCTP (and also ANBdCTP) by $P$. polycephalum DNA polymerase $\alpha$ preferentially in the $\mathrm{dC}$ position and with lower frequencies in the $\mathrm{dT}$, $\mathrm{dA}$ and $\mathrm{dG}$ positions.

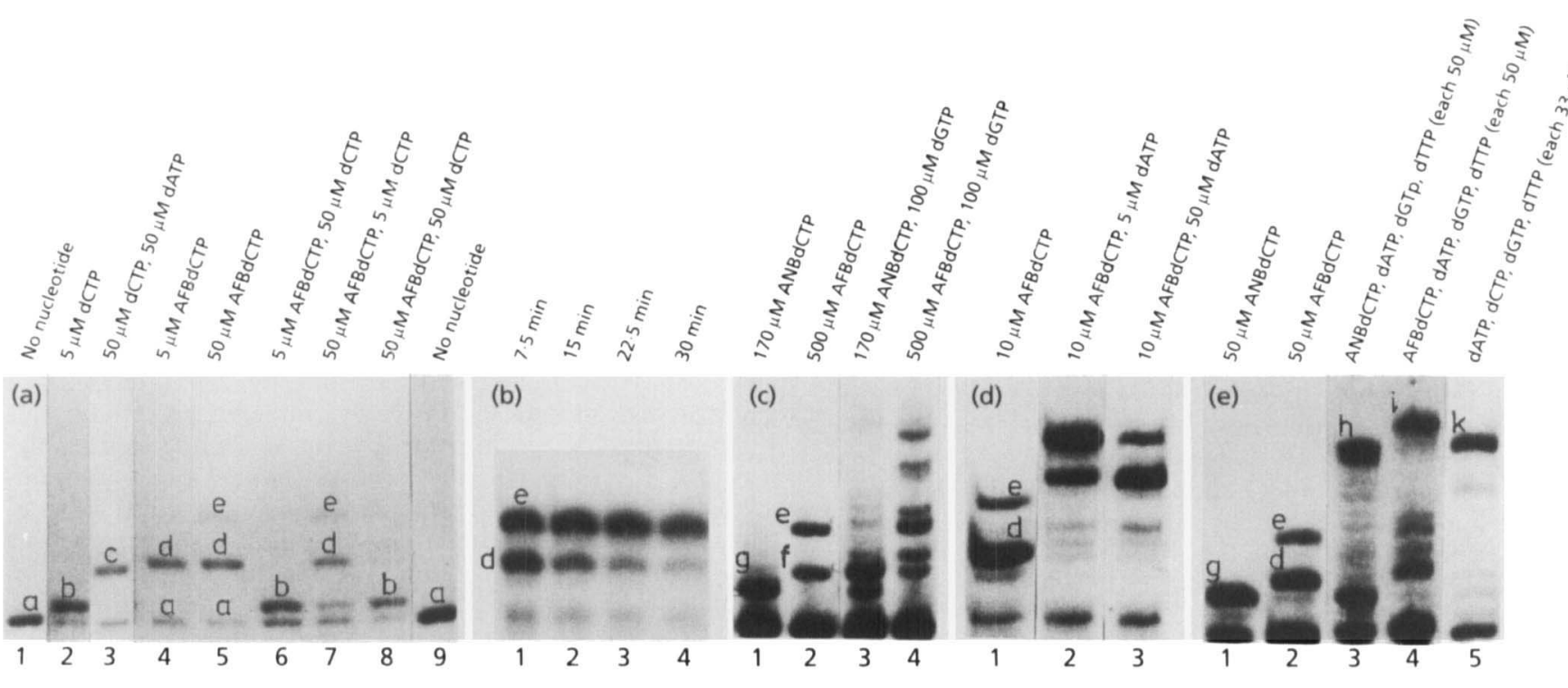

Fig. 2. Incorporation of photoreactive nucleotides during primer extension. Denaturing urea gels are shown for products obtained by extension of synthetic $5^{\prime}-\left[^{32} \mathrm{P}\right] 16$-mer primer/26-mer template $(0.1 \mu \mathrm{M})$ with various nucleotides. The reaction was catalysed by 0.015 units DNA polymerase $\alpha$. (a) Demonstration of competition between AFBdCTP and dCTP. (b) Time dependence of incorporation of AFBdCTP $(50 \mu \mathrm{M})$. (c) Effect of added dGTP on primer extension; M13mp18 DNA was the template. (d) Effect of added dATP on primer extension; synthetic 26 mer-DNA was the template. (e) Extension of 5'[32P]16-mer primer/26-mer template with ANBdCTP or AFBdCTP in the presence of complementary dNTPs. 

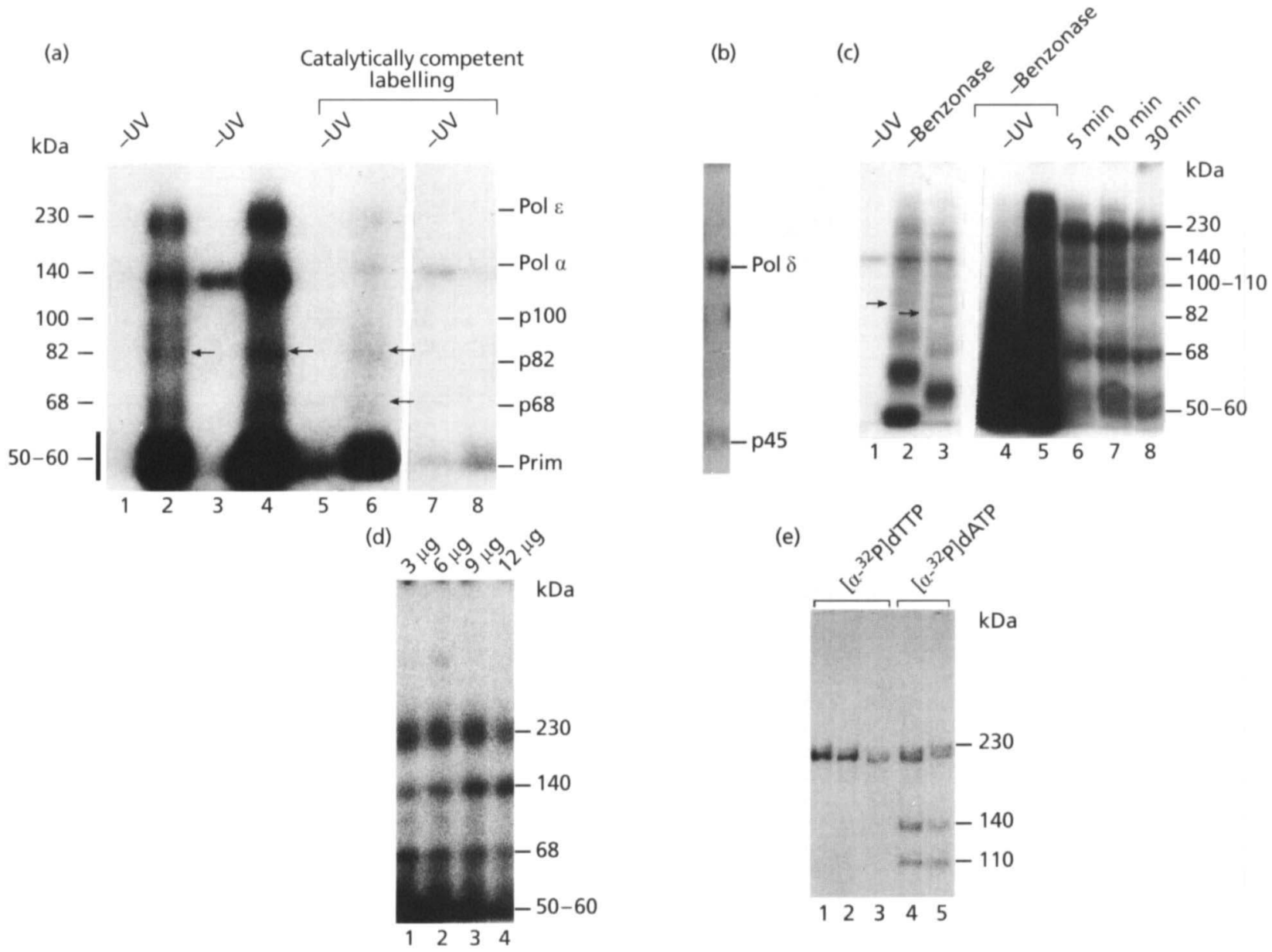

Fig. 3. Photoaffinity labelling of purified DNA polymerases from $P$. polycephalum. The standard labelling conditions were used, with $0.2 \mu \mathrm{M}$ synthetic 26 -mer template/16-mer primer, $50 \mu \mathrm{M}$ AFBdCTP, $3 \mu \mathrm{M}\left[\alpha^{32} \mathrm{P}\right] \mathrm{dATP}\left(3 \mathrm{Ci} \mathrm{mmol}{ }^{-1}\right)$, 0.1-0.3 units DNA polymerase, and autoradiography from membranes after electroblotting (see also Methods). '-UV' denotes controls without irradiation. (a) Lanes 1 and 2, 0.12 units DNA polymerase; digestion with nuclease omitted. Lanes 3 and 4, the same but 0.24 units DNA polymerase. Lanes 5 and 6 , same as in lanes 3 and 4 but using the catalytically competent condition employing the 26-mer template $/ 5^{\prime}-\left[{ }^{32} \mathrm{P}\right] 16-$ mer primer. DNA was not digested. To test for primer extension, unlabelled 26-mer template/16-mer primer was cross-linked to polymerase first, and [ $\alpha$-32P]dATP was then added (lanes 7 and 8). (b) DNA polymerase $\delta$. (c) DNA digestion by benzonase following photolabelling. Lanes 1-3, synthetic template-primer in the absence (lane 2) and the presence (lane 3) of benzonase; lanes 4-8, activated salmon testis DNA in the absence (lanes 4 and 5) and in the presence (lanes 6-8) of benzonase; lanes 6-8, digestion for 5, 10 and $30 \mathrm{~min}$ at $37^{\circ} \mathrm{C}$. (d) Labelling in the presence of 3,6,9 and $12 \mu \mathrm{g}$ activated DNA. The reaction mixture also contained dGTP and dTTP. DNA was digested after photo-cross-linking. (e) Comparison of synthetic template-primer with activated DNA and of $\left[\alpha^{32}\right.$ P]dATP with [ $\alpha{ }^{32}$ P]dTTP. Reaction mixtures contained $100 \mu \mathrm{M}$ AFBdCTP. DNA was digested after UV irradiation. Lanes $1-3,2.8 \mu \mathrm{M}\left[\alpha^{-32} \mathrm{P}\right] \mathrm{dTTP}\left(50 \mathrm{Ci} \mathrm{mmol}^{-1}\right)$, dATP, dGTP; lanes 4 and $5,2.8 \mu \mathrm{M}\left[\alpha^{-32} \mathrm{P}\right] \mathrm{dATP}\left(50 \mathrm{Ci}^{\mathrm{mmol}}{ }^{-1}\right)$, dGTP, dTTP; lanes 1 and 4, synthetic 26-mer template/16-mer primer; lanes 2, 3 and 5, activated DNA.

\section{Labelling of purified DNA polymerases from P. polycephalum}

Photoaffinity labelling was first applied to purified DNA polymerases to test its efficacy and to optimize the assay conditions. The method was then intended to be used to identify and purify $P$. polycephalum DNA polymerase $\varepsilon$. The final goal was to characterize $P$. polycephalum cellular extracts. To optimize the cross-linking conditions, the synthetic template-primer originally used was replaced by the less expensive and abundantly available DNase-I-activated salmon testis DNA. Excess DNA was removed by digestion with the nuclease benzonase. After electrophoretic separation, the labelled proteins were concentrated by electroblotting onto the surface of a membrane. The time for autoradiography was extended from $12 \mathrm{~h}$ to $6-8 \mathrm{~d}$.

The intensities after improvement of the method are shown in Fig. 3 for purified P. polycephalum DNA polymerases. The effect of DNA digestion is noted as an increase in electrophoretic mobility for the synthetic template-primer in Fig. 3(c), lanes 2 and 3, and as a resolution into bands for activated salmon testis DNA in Fig. 3(c), lanes 5 and 6 . The labelled oligonucleotide tag, which remained attached after digestion, tended to 
(a)

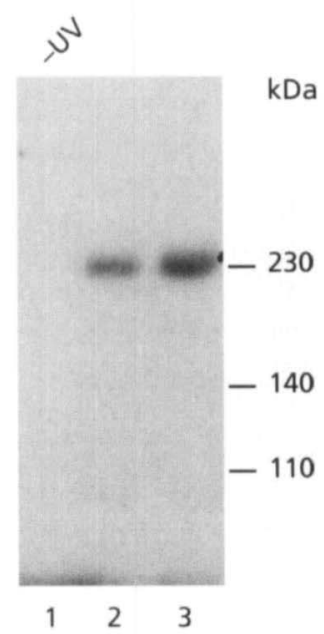

(b)

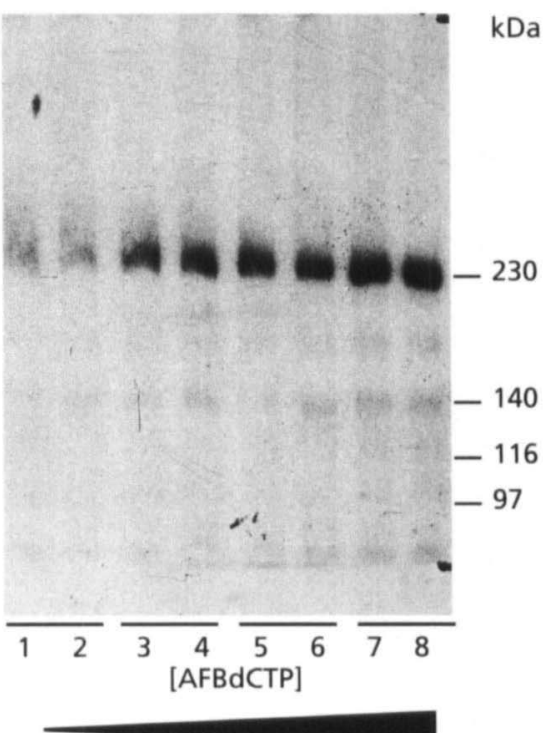

(c)

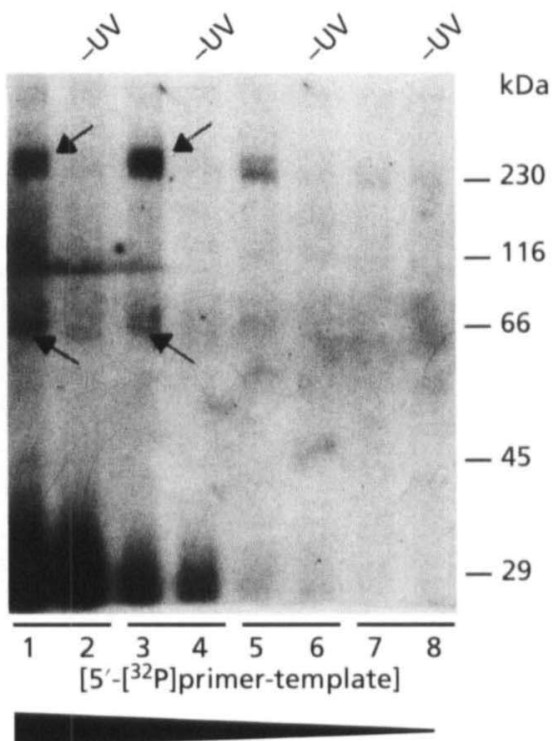

Fig. 4. Photoaffinity labelling of purified DNA polymerase $\varepsilon$. Standard labelling conditions and DNA digestion were employed unless indicated otherwise. (a) $0.2 \mu \mathrm{M}$ synthetic 26 -mer template/16-mer primer, $2.2 \mu \mathrm{M}$ [ $\left.\alpha_{-}{ }^{32} \mathrm{P}\right] \mathrm{dATP}$ (10 Ci $\mathrm{mmol}^{-1}$ ), dGTP, dTTP (each $33 \mu \mathrm{M}$ ), 0.25 units (lane 2) or 0.5 units (lane 3) DNA polymerase $\varepsilon$. Lane 1, dark control. (b) Dependence on AFBdCTP concentration (each concentration in duplicate): $5 \mu \mathrm{M}$ (lanes 1 and 2), $10 \mu \mathrm{M}$ (lanes 3 and 4), $20 \mu \mathrm{M}$ (lanes 5 and 6 ), and $50 \mu \mathrm{M}$ (lanes 7 and 8 ) AFBdCTP. Reaction mixtures contained $3 \mu \mathrm{g}$ activated DNA, $2.8 \mu \mathrm{M}$ [ $\alpha$ ${ }^{32}$ P]dTTP $\left(50 \mathrm{Ci} \mathrm{mmol}^{-1}\right)$, dATP, dGTP and 0.25 units DNA polymerase $\varepsilon$. (c) Labelling in the presence of $5^{\prime}-\left[^{32} \mathrm{P}\right] 16-\mathrm{mer}$ primer $\left(3000 \mathrm{Ci} \mathrm{mmol}^{-1}\right) / 26$-mer template at varying concentrations: $0.2 \mu \mathrm{M}$ (lanes 1 and 2), $0.07 \mu \mathrm{M}$ (lanes 3 and 4), $0.02 \mu \mathrm{M}$ (lanes 5 and 6 ) and $0.007 \mu \mathrm{M}$ (lanes 7 and 8). Reaction mixtures contained $50 \mu \mathrm{M}$ AFBdCTP and 0.25 units DNA polymerase.

increase the molecular mass in comparison with the non-labelled proteins. We found that the increase was reproducible (Fig. 3c, lanes $6-8$ ) and was an intrinsic property of each protein. It was $5-15 \mathrm{kDa}$ for DNA polymerases and their subunits. For replication factors and histones (see below) an increase was almost undetectable. Among the various types of templateprimers examined [including poly $(\mathrm{rA}) / \mathrm{p}(\mathrm{dT})_{12-18}(10 / 1)$, poly $(\mathrm{dA}) / \mathrm{p}(\mathrm{dT})_{12-18}(10 / 1)$ and poly $(\mathrm{dT}) / \mathrm{p}(\mathrm{rA})_{10}(20 / 1)$, results not shown], activated DNA and the synthetic template-primer were optimal and gave comparable results (Fig. 3c, lanes 3, 6-8). In the absence of UV irradiation, labelling was not observed; in cases, such as that in Fig. 3(a) lane 7, samples were probably insufficiently protected against light.

The bands in Fig. 3 (except panel b) were reconcilable with the reported molecular masses of subunits of the DNA polymerase $\alpha$-primase complex. The subunits are listed on the right side of Fig. 3(a) and refer to the $140 \mathrm{kDa}$ DNA polymerizing unit, the $82 \mathrm{kDa}$ interconnecting protein, and the $58 \mathrm{kDa} / 53 \mathrm{kDa}$ primase subunits (Weber et al., 1988; Achhammer et al., 1992; Angerer \& Holler, 1995). The band at $82 \mathrm{kDa}$ was only stained in the presence of the synthetic template-primer (arrows in Fig. 3). It is not clear why it was not seen in the presence of activated DNA (Fig. 3c, lanes 6-8, and Fig. 3d). Other labelled bands, especially those at 100 and $110 \mathrm{kDa}$ in Fig. 3(a), lane 2, Fig. 3(c), lanes 6-8, and
Fig. 3(e), lanes 4 and 5, were ascribed to proteolytic degradation products of DNA polymerase $\alpha$ (Weber $e t$ al., 1988). For DNA polymerase $\delta$ in Fig. 3(b), bands at 140 and $45 \mathrm{kDa}$ were identified. They could be attributed to the polymerizing ( $125 \mathrm{kDa}$ ) subunit and to an additional subunit (approximately $40 \mathrm{kDa}$ ) of unknown function by relating them to the existence of subunits in mammalian or Saccharomyces cerevisiae DNA polymerase $\delta$ (125 kDa polymerizing subunit and $50-53 \mathrm{kDa}$ subunits of unknown functions: Zhang et al., 1995; Sugimoto et al., 1995).

The bands at 230 and $68 \mathrm{kDa}$ could not be reconciled with known $P$. polycephalum DNA polymerases or their degradation products. The possibility that the bands at 68 and $230 \mathrm{kDa}$ in Fig. 3(a, c-e) resulted from nonspecific labelling was first considered. However, their intensities depended on the protein concentration (Fig. $3 \mathrm{a}$, lanes 2 and 4). A dependence on the concentration of activated DNA is seen for the band at $140 \mathrm{kDa}$ (the DNA-polymerizing subunit) but not for the bands at 68 and $230 \mathrm{kDa}$ in Fig. 3(d). This seemed to indicate different DNA binding affinities. Addition of dGTP and dTTP, each at $33 \mu \mathrm{M}$, substantially increased the band intensities (data not shown). The presence of dCTP $(500 \mu \mathrm{M})$ in large excess over AFBdCTP $(50 \mu \mathrm{M})$ inhibited labelling (data not shown), in agreement with the competitive status of these nucleotides. The 110 and $140 \mathrm{kDa}$ proteins were labelled when $\left[\alpha^{-32} \mathrm{P}\right] \mathrm{dATP}$ (Fig. 


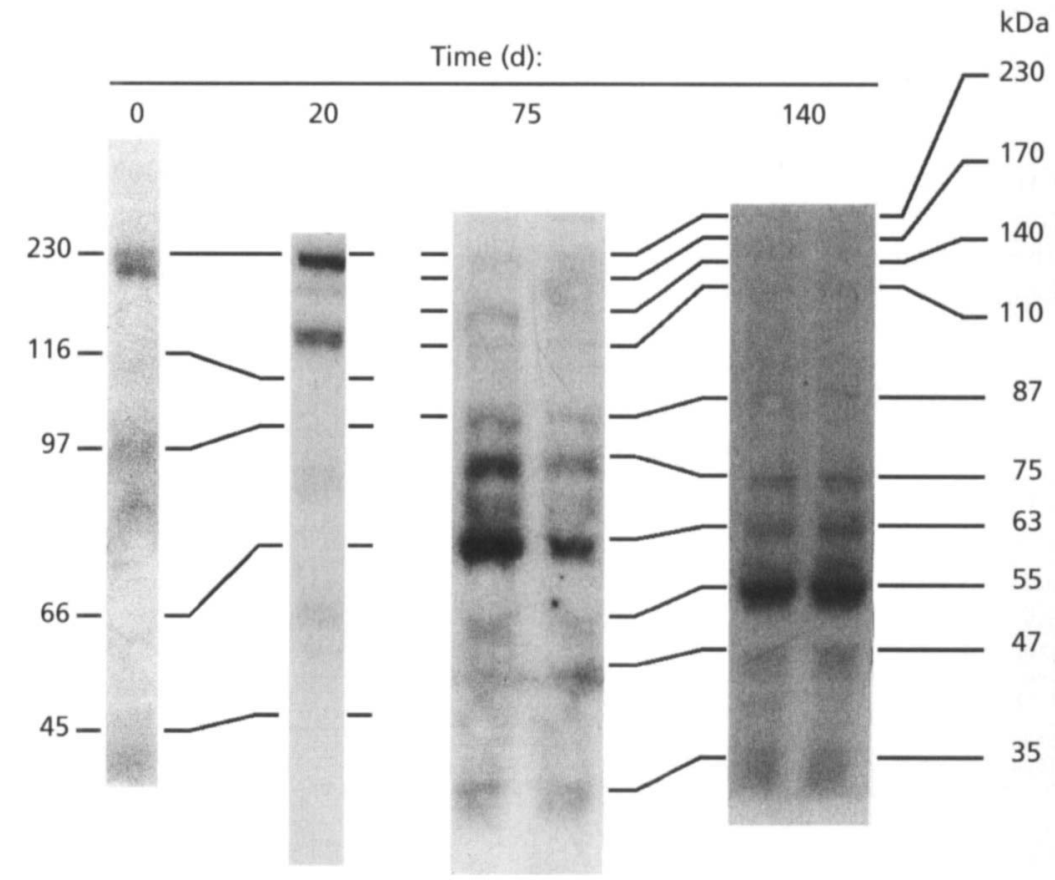

\begin{abstract}
Fig. 5. Photoaffinity labelling of spontaneously degrading purified DNA polymerase $\varepsilon$. Samples of DNA polymerase $\varepsilon$ kept at $-20^{\circ} \mathrm{C}$ were analysed at the indicated times. Standard labelling conditions included activated DNA, $50 \mu \mathrm{M}$ AFBdCTP, dGTP and dTTP ( $33 \mu \mathrm{M}$ each),

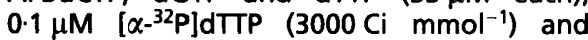
digestion with benzonase. Polymerase activity according to the standard assay was 0.5 units at day zero and 0.4 units after $140 \mathrm{~d}$. The results for 75 and $140 \mathrm{~d}$ are shown in duplicate.
\end{abstract}

3e, lanes 4 and 5) but not when $\left[\alpha-{ }^{32} \mathrm{P}\right] \mathrm{dTTP}$ (Fig. 3e, lanes 1-3) was used. This variation in labelling was not related to the kind of template-primer, as seen by comparison of lanes 1 and 4 (synthetic template-primer) and of lanes 2, 3 and 5 (activated DNA) in Fig. 3(e). As shown in Fig. 2, the reaction with polymerase $\alpha$ (band at $140 \mathrm{kDa})$ implied that AFBdCTP $(100 \mu \mathrm{M})$ competed with $\left[\alpha^{32} \mathrm{P}\right] \mathrm{dTTP}(2 \cdot 8 \mu \mathrm{M})$ and eliminated incorporation of radioactivity into the cross-linking DNA. The labelling of the protein at $230 \mathrm{kDa}$ could be explained if primer was extended by a kind of DNA polymerase that did not accept AFBdCTP in the wrong position, ruling out competition, and supporting the labelling. This DNA polymerase must be less promiscuous than DNA polymerase $\alpha$ in base recognition.

To test whether non-specific cross-linking of labelled DNA and proteins could occur by a collisional encounter, the effect of $2 \mathrm{mg}$ bovine serum albumin $\mathrm{ml}^{-1}$ in the reaction mixture containing DNA polymerase $\alpha$ was examined. Labelled serum albumin was not detectable, and the intensities of the bands were not changed (data not shown). Also, unspecific labelling of proteins was not observed when cytoplasmic extract was assayed (see below). The specificity of the technique was further supported by the results of catalytically competent labelling, which was introduced by Mitina et al. (1990) and Lavrik et al. (1996). In this variant, the photoreactive nucleotide is first allowed to bind and photocross-link in the dNTP substrate pocket before it is ligated by polymerase transfer activity to the $5^{\prime}-\left[{ }^{32} \mathrm{P}\right]$ primer-template. If the spacer between the photoreactive moiety and the nucleotide part of AFBdCTP was sufficiently long and flexible, polypeptide residues distant from the nucleotide-binding site but in the same polymerase complex could be attacked. The subunits of DNA polymerase holoenzymes were labelled in Fig. 3(a), lane 6 (see arrows), validating the results of classical photoaffinity labelling. Bands were less intense due to the low level of cross-linking in this version of the technique. Fig. 3(a), lane 8 , is a control in which $\left[\alpha-{ }^{32} \mathrm{P}\right] \mathrm{dATP}$ was added after ligation of unlabelled template-primer to polymerase-cross-linked AFBdCTP. The absence of bands in the $230 \mathrm{kDa}, 97 \mathrm{kDa}, 82 \mathrm{kDa}$ and $68 \mathrm{kDa}$ positions excluded the possibility of uncontrolled labelling by residual AFBdCTP. All these results were consistent with the bands at 68 and $230 \mathrm{kDa}$ being products of affinity labelling.

\section{Identification of DNA polymerase $\varepsilon$}

Proteins identified by the labelled bands at 68 and $230 \mathrm{kDa}$ were purified from plasmodial extracts employing the photoaffinity labelling assay. The purified preparation confirmed the labelling (Fig. 4c, arrows in lanes 1 and 3$)$. The intensity depended on the concentrations of protein (Fig. 4a), AFBdCTP (Fig. 4b), and activated DNA (Fig. 4c). The purified preparation was able to support DNA synthesis, preferring poly $(\mathrm{dA}) /$ $\mathrm{p}(\mathrm{dT})_{12-18}$ over activated DNA as template-primer and had an intrinsic $3^{\prime}-5^{\prime}$-exonuclease proofreading activity (data not shown). Activity was inhibited by $\mathrm{N}$-ethylmaleimide $(70 \%$ inhibition at $1.2 \mathrm{mM})$, aphidicolin ( $50 \%$ inhibition at $\left.5 \mu \mathrm{g} \mathrm{ml}^{-1}\right)$, dimethylsulfoxide $(50 \%$ inhibition at $10 \%$ aqueous dimethylsulfoxide), butylphenyl-dGTP $(83 \%$ at $10 \mu \mathrm{M})$ and heparin $(30 \%$ at $0 \cdot 22 \mu \mathrm{g} \mathrm{ml}^{-1}$ ). The results fitted the published criteria for type $\varepsilon$ DNA polymerase, the protein at $230 \mathrm{kDa}$ representing the polymerizing subunit, and the protein at $68 \mathrm{kDa}$, a subunit of unknown function. Corresponding sizes have been reported for DNA polymerase $\varepsilon$ of $S$. cerevisiae (for a recent review see Sugino, 1995) and higher eukaryotes (Chui \& Linn, 1995; for a recent 
review see also Hindges \& Hübscher, 1997). The $\varepsilon$-type of polymerase is known to synthesize DNA with higher processivity and fidelity than the $\alpha$-type, in agreement with the labelling patterns noticed in Fig. 3(e). When tested for its sensitivity towards PMLA, $P$. polycephalum DNA polymerase $\varepsilon$ was inhibited to $50 \%$ in the presence of $0.4 \mu \mathrm{g}$ polymer $\mathrm{ml}^{-1}$, in agreement with the findings for DNA polymerase $\alpha$ and $\delta$ of $P$. polycephalum (Fischer et al., 1989; Achhammer et al., 1995).

\section{Labelling of nicked DNA polymerases}

In Fig. 3(a, c, e), 100 and $110 \mathrm{kDa}$ labelled proteins were fragments of DNA polymerase $\alpha$. In Fig. 5 , on storage of DNA polymerase $\varepsilon$ at $-20^{\circ} \mathrm{C}$, photolabelled polypeptides decreased in size dramatically (from 230 to $30-70 \mathrm{kDa}$ ). This was accompanied by a $40 \%$ decrease in activity by the standard polymerase assay. Thus even extensive proteolytic nicking does not necessarily abolish polymerase activity for affinity labelling. DNA polymerase $\varepsilon$ has been reported to be particularly sensitive to proteolysis in preparations from several organisms (Kesti \& Syvaoja, 1991; Uitto et al., 1995).

\section{Photoaffinity labelling of cellular extracts}

In investigating the cytoplasmic and nuclear extracts of plasmodia we asked the following questions. (i) Is the technique sensitive enough to detect DNA polymerases in plasmodial extracts? (ii) Are DNA polymerases and replication factors restricted to nuclei? (iii) Are DNA polymerases and subunits labelled to equal intensities in purified preparations and extracts? (iv) Are the equivalents of PCNA, RP-A and RF-C labelled, and how do their molecular masses compare with those from yeast and higher eukaryotes? (v) Is labelling affected by PMLA? (vi) Does the pattern of labelled proteins change during (natural) growth arrest?

A variety of proteins were labelled in the nuclear extract (Figs 6-8). Electroblotting improved their detection (Fig. $6 a$, lanes 1-6). Band patterns were similar for AFBdCTP in (Fig. 6a, lane 5) and ANBdCTP in (Fig. 6a, lane 7), albeit of higher intensity for the former. DNA polymerases $\alpha$ and $\varepsilon$ were among the labelled proteins identified in Fig. 6(b), lanes 1 and 2. The immunostained bands matched the subunits. Antiserum against DNA polymerase $\delta$-peptide stained a band of $125 \mathrm{kDa}$ in Fig. $6(\mathrm{~b})$, lane 3 . Taking into account $15 \mathrm{kDa}$ of the $\left.{ }^{32} \mathrm{P}\right] \mathrm{DNA}$-tag after labelling, the band would be shifted into the $140 \mathrm{kDa}$ position. This was the region of bands for labelled type- $\alpha$ and $\beta$-like DNA polymerases $(135 \mathrm{kDa}$ for unlabelled $\beta$-like DNA polymerase; Holler et al., 1987). The proximity of several bands was indicated by the relatively broad labelling in the 135-150 kDa region (for instance in Fig. 6b, lanes 2, 6 and 8, and in Fig. 7a, lanes 1 and 3).

Antiserum against human PCNA heavily stained a protein at $46 \mathrm{kDa}$ (Fig. $6 \mathrm{~b}$, lane 5 ) that was also intensely labelled (Fig. 6b, lane 6). In the DNA metabolism of eukaryotes PCNA is an indispensable factor that, among several other functions, enhances the processivity of DNA synthesis by DNA polymerase $\delta$. It is a highly conserved $37 \mathrm{kDa}$ polypeptide that oligomerizes to form a doughnut-like DNA clamp (for a recent review see Hübscher et al., 1996). A $46 \mathrm{kDa}$ PCNA analogue would thus be unusual. Its heavy immunostaining and photolabelling indicate that the $46 \mathrm{kDa}$ PCNA-like species was very abundant and probably significant. We have recently purified and characterized a $35 \mathrm{kDa}$ PCNA in $P$. polycephalum (Achhammer et al., 1995). It is now assumed that this form of PCNA is the product of partial proteolysis. The $46 \mathrm{kDa}$ PCNA is similar in mass to the labelled $40 \mathrm{kDa}$ subunit of DNA polymerase $\delta$ seen in Fig. 3(b). It presumably also functions as a subunit of DNA polymerase $\delta$.

Staining with antiserum against the $70 \mathrm{kDa}$ subunit of human RP-A indicated bands at $54 \mathrm{kDa}$ (intense) and $62 \mathrm{kDa}$ (weak) (Fig. 6b, lane 7). Intense labelling could be observed for the $54 \mathrm{kDa}$ band (Fig. $6 \mathrm{~b}$, lane 8 ). Labelling of the $70 \mathrm{kDa}$ subunit of human RP-A has been reported recently, demonstrating accessibility of the factor to photoreactive DNA (Lavrik et al., 1998). RP-A is a heterotrimeric, single-stranded DNA-binding protein required for eukaryotic DNA metabolism (for a recent review see Wold, 1997). The molecular mass of the large $P$. polycephalum RP-A subunit could be reconciled with the size $(53 \mathrm{kDa})$ of a proteolytic fragment derived from the bovine $70 \mathrm{kDa}$ RP-A protein (Nasheuer et al., 1992).

Antiserum against yeast RF-C subunit $\mathrm{C} 4$ stained bands at 31,38 (barely visible), and $72 \mathrm{kDa}$ (Fig. $6 \mathrm{c}$, lane 1 ). Marginal labelling was also observed at 31 and $36 \mathrm{kDa}$, and no labelling at $72 \mathrm{kDa}$ (arrows in Fig. $6 \mathrm{c}$, lanes 2 and $3)$. In yeast and higher eukaryotes, RF-C is a complex of polypeptides with molecular masses of approximately $140,40,38,37$ and $36 \mathrm{kDa}$. It is an essential component of the replication machinery of eukaryotes, functioning in the loading of the PCNA clamp to DNA (for a recent review see Hübscher et al., 1996). The indication of three bands for RF-C in Fig. 6(c) is in agreement with the cross-reactivity of the antibody to the three small subunits of RF-C from S. cerevisiae (Gary \& Burgers, 1995). The low level of photoaffinity labelling is reconciled with the low abundance of this factor.

The identity and functions of DNA polymerases were supported by the responses to specific inhibitors of DNA synthesis. Aphidicolin, a known inhibitor of DNA polymerases $\alpha, \delta$ and $\varepsilon$ (Weber et al., 1988; Angerer \& Holler, 1995; Achhammer et al., 1995; this work), inhibited labelling of bands in positions $140-230 \mathrm{kDa}$, in agreement with the presumed types of polymerases banding in these positions (arrows in Fig. 7b, lanes 3-6). Dinucleotide oligophosphates $A \mathrm{p}_{4} \mathrm{~A}$ and $A \mathrm{p}_{3} \mathrm{~A}$, which are contained in plasmodia of $P$. polycephalum (Garrison \& Barnes, 1992), are considered to be alarmones that arrest growth in response to environmental stress (for a review see Remy, 1992). These 
(a)

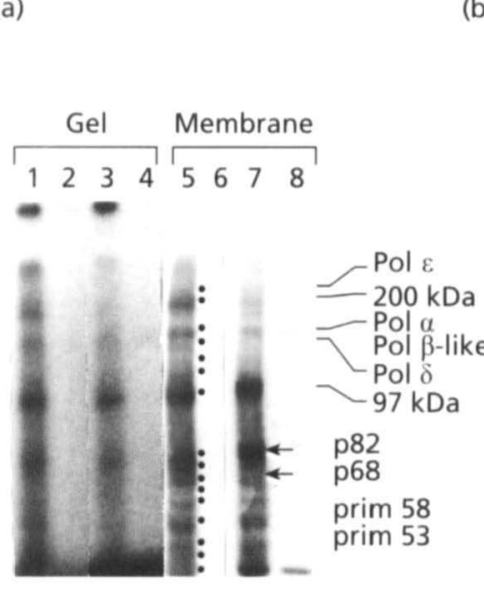

(b)

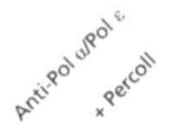

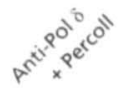

(10)
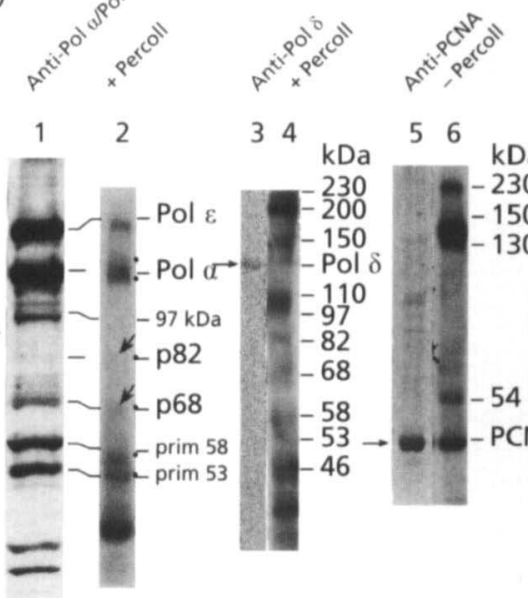

34

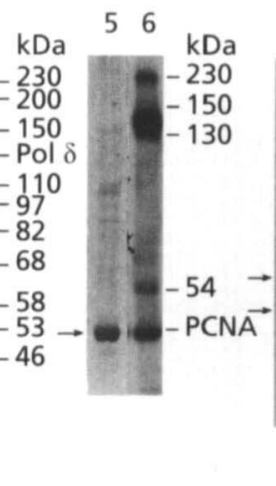

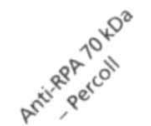

78

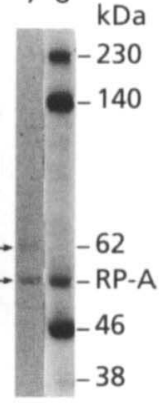

(c)

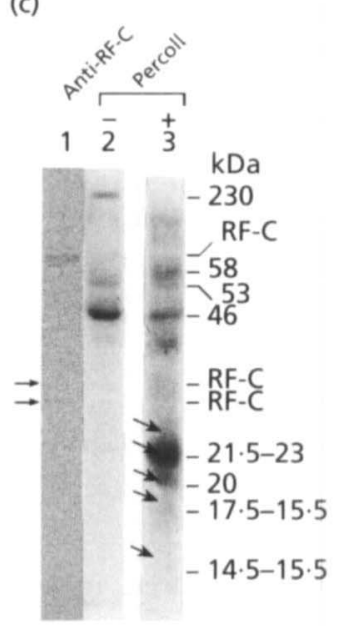

Fig. 6. Western blots and photoaffinity labelling of DNA polymerases and factors in nuclear extracts. Extracts were prepared from nuclei of 2- and 3-d-old microplasmodia by centrifugation over a Percoll density gradient unless stated otherwise. The standard assay was used for labelling. (a) Increase in resolution and intensity by electroblotting before autoradiography; 3-d-old plasmodia were compared for AFBdCTP or ANBdCTP in the reaction mixture. Lanes 1-4, autoradiography of a dried SDS-polyacrylamide (7.5\% acrylamide) gel. Lanes 5-8, autoradiography of the membrane after electroblotting; lanes 1 and 5, $100 \mu \mathrm{M}$ AFBdCTP ( 2 min UV irradiation); lanes 3 and 7, $100 \mu \mathrm{M}$ ANBdCTP ( 2 min UV irradiation); lanes 2, 4, 6 and 8 are controls in the absence of irradiation. Positions of bands are marked by dots in lane 5 . (b) Comparison of band patterns obtained by Western blotting and photoaffinity labelling. Lane 1, Western blot (ECL staining) with antiserum against DNA polymerases $\alpha$ and $\varepsilon$ for 2-3-d-old plasmodia; lane 2, photoaffinity labelling for 2d-old plasmodia; lane 3, Western blot for 3-d-old plasmodia with antiserum against DNA polymerase $\delta$-peptide; lane 4 , labelling of the sample shown in lane 3; lane 5, Western blot with antiserum against human PCNA for 2-d-old plasmodia (Percoll absent); lane 6, labelling of the sample shown in lane 5; lane 7, Western blot with antiserum against human RP-A (70 kDa subunit) for 2-d-old plasmodia (Percoll absent); lane 8, labelling of the sample shown in lane 7. (c) Comparison of low-molecular-mass polypeptides for 2-d-old plasmodia after SDS-PAGE (15\% acrylamide). Note that electroblotting of high-molecular-mass proteins was incomplete. Lane 1 , Western blot with antiserum against yeast RF-C subunit 4 (Percoll absent); lane 2, labelling of the sample as shown in lane 1; lane 3, labelling of the sample shown in lane 2 , but in the presence of $25 \%(\mathrm{v} / \mathrm{v})$ Percoll.

effectors inhibited labelling (Fig. 7b, lanes 7 and 8), suggesting that they function as inhibitors of DNA synthesis in $P$. polycephalum.

The presence of $25 \%(\mathrm{v} / \mathrm{v})$ Percoll, a reagent routinely employed for the preparation of 'clean' nuclei by density-gradient centrifugation (e.g. Angerer \& Holler, 1995), provoked leakage of proteins from the nuclei. DNA polymerase $\varepsilon, 46 \mathrm{kDa}$ PCNA-like protein, and $54 \mathrm{kDa}$ RP-A-like protein (Fig. 7a, lanes 1-3) were identified. These proteins could be depleted from the nuclei (Fig. 7a, lane 3), except for DNA polymerase $\varepsilon$, which remained in an approximately equal amount in the washed nuclei (Fig. 7a, lanes 2 and 3). Percoll also enhanced the intensity of other labelled bands, some of them not found in its absence (e.g. Fig. 6c, lanes 2 and 3). Bands of DNA polymerase subunits indicated by arrows were one example (Fig. 6a, lane 7; Fig. 6b, lane 2; Fig. $7 \mathrm{a}$, lane 3 ; Fig. $7 \mathrm{~b}$, lanes 1 and 3 ). Bands in positions $14 \cdot 5-23 \mathrm{kDa}$ (arrows in Fig. 6c, lane 3) with molecular masses reminiscent of $P$. polycephalum histones (Cote $e t$ al., 1985) provided another example. It has to be noted that in Fig. $6(\mathrm{c})$ bands at $>100 \mathrm{kDa}$ were not efficiently electroblotted due to the high concentration $(15 \%)$ of polyacrylamide. The missing bands were, however, identified in the electrophoretic gel (not shown). The cytoplasmic fraction, assessed without Percoll addition, was devoid of labelled bands.

The observation that histones and certain subunits of DNA polymerases were not labelled in the extract when Percoll was absent raised a question about inaccessibility to photoreactive DNA. These proteins were presumed to be masked by participating in higher-order complex(es) of DNA polymerase holoenzymes, histones, and probably other polypeptides. Percoll disrupted the complex and restored access similar to that in purified preparations. A candidate agent that promoted the formation of such higher-order complexes was PMLA. We examined different concentrations of the polymer; the results for some of them are shown in Fig. 7(c). The effects on labelling were spectacular. At $5 \mu \mathrm{g}$ endogenous PMLA ml ${ }^{-1}$ in the labelling mixture (arrows in Fig. 7c, lane 2), inhibition was relieved by the presence of $0.2 \mathrm{mM}$ added spermine. $\mathrm{HCl}$ (Fig. $7 \mathrm{c}$, lane 1) as described by Angerer \& Holler (1995). At $75 \mu \mathrm{g} \mathrm{ml}^{-1}$ (Fig. 7c, lane 3) and higher PMLA concentrations, labelling of all but the two bands at 200 and $140 \mathrm{kDa}$ was suppressed. The $200 \mathrm{kDa}$ band was related to DNA polymerase $\varepsilon$ by immunostaining. The $140 \mathrm{kDa}$ band was referred to $\beta$-like DNA polymerase because of its resistance to PMLA inhibition (Fischer et al., 1989). We 
(a)
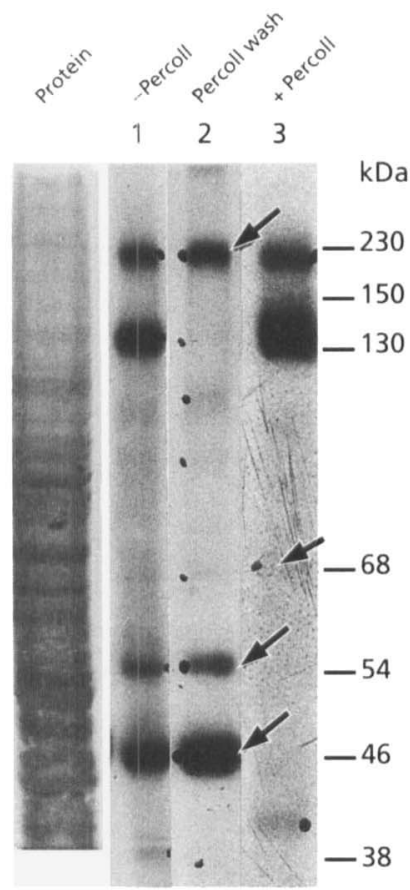

(b)
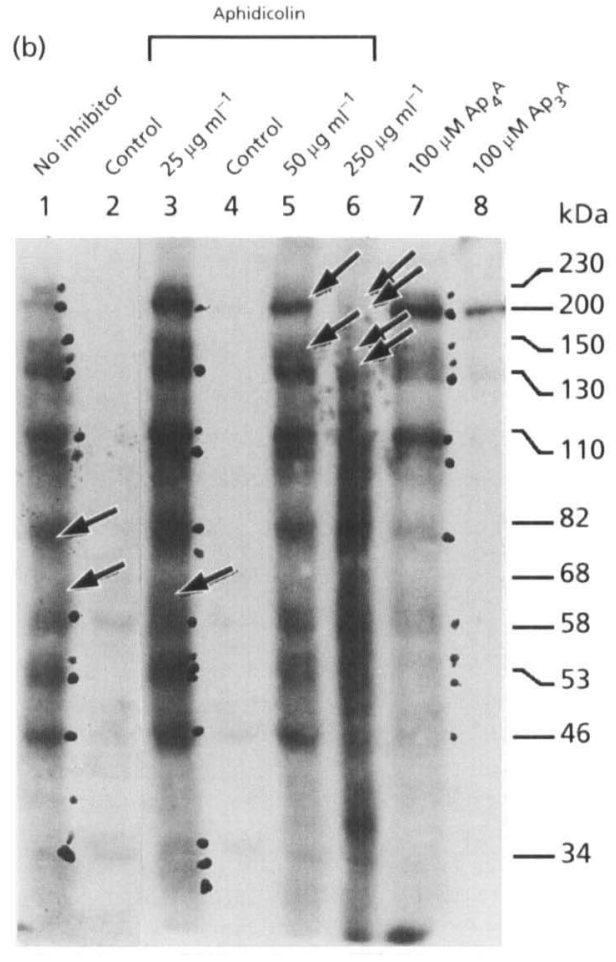

(c)
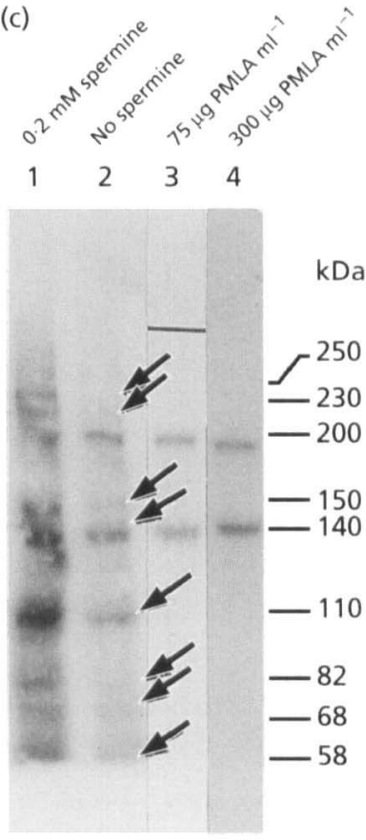

Fig. 7. Percoll and effectors of DNA polymerases. (a) Effect of washing nuclei (from 2-d-old plasmodia) with Percollcontaining buffer (see Methods). Nuclei were prepared in the absence of Percoll. The lane 'Protein' indicates nuclear extract (Percoll absent) stained with Coomassie Brillant Blue. One aliquot of nuclei was washed with buffer, and the nuclear extract labelled (lane 1). One aliquot was washed with Percoll $(25 \%$, v/v) buffer, and the wash was labelled (lane 2). The extract of the Percoll-washed nuclei was labelled (lane 3). (b) Effect of inhibitors in the standard labelling mixture. Nuclei of 3-d-old plasmodia were prepared in the presence of Percoll. Labelled proteins were separated by SDS-PAGE (10\% acrylamide). Lanes 1 and 2, absence of inhibitors; lanes 3-8, inhibitors and concentrations as indicated; lanes 2 and 4, controls in the absence of AFBdCTP. (c) PMLA was present at approximately $5 \mu \mathrm{g} \mathrm{ml}^{-1}$ in the standard labelling mixture due to endogenous inhibitor in the extract (3-d-old plasmodia, Percoll present). Labelled proteins were separated by SDSPAGE (7.5\% acrylamide). The labelling mixture contained $0.2 \mathrm{mM}$ spermine. $\mathrm{HCl}$ in lane 1 . PMLA was added in the indicated concentrations in lanes 3 and 4.

concluded that the variation in labelling was due to the complex-forming activity of PMLA.

DNA-replicating polymerases are believed to be cleared from the nuclei concomitantly with growth arrest. Plasmodia start to arrest $2 \mathrm{~d}$ after inoculation, while the level of PMLA remains high until day 5 (Holler et al., 1992a). On that basis, the higher-order complexes of PMLA would have to be cleared from the nuclei. A comparison for $2 \mathrm{~d}$ plasmodia (Percoll present in Fig. 7a, lane 3; Percoll absent in Fig. 7a, lane 1, and Fig. 8, lanes 9 and 10) and $3 \mathrm{~d}$ plasmodia (Percoll present in Fig. $7 \mathrm{~b}$, lane 1 ; Percoll absent in Fig. 8, lanes 11 and 12) suggested that nicked DNA polymerases were accumulated in the nuclei. Immunostaining indicated that fragment bands were generated especially from DNA polymerases $\alpha$ and $\varepsilon$. Despite nicking, labelling activities were maintained in the nuclei similarly as during nicking of purified DNA polymerase $\varepsilon$ in Fig. 5. Fragmentation/nicking was not observed during the mitotic cycle (data not shown). We assumed that it was essential for the removal of DNA polymerases from the nuclei. That nicking was not an experimental artefact is supported by the following arguments: (i) protease inhibitors were present during sample preparation; (ii) prolonged standing of nuclei or nuclear extract did not change the band patterns; (iii) if $3 \mathrm{~d}$ plasmodia contained proteolytic activities that introduced nicks during sample preparation, new bands would have been generated in extracts of $2 \mathrm{~d}$ plasmodia after mixing with $3 \mathrm{~d}$ plasmodia (Fig. 8, lanes 2-7). Also, mixing of the two nuclear extracts did not have this effect (Fig. 8, lanes 13 and 14).

\section{Conclusions}

The results for purified DNA polymerases indicated that their labelling and identification was possible. A labelled band of $230 \mathrm{kDa}$ enabled us to isolate and identify $P$. polycephalum DNA polymerase $\varepsilon$. This type of polymerase has been shown to be present in yeast and metazoans (Hindges \& Hübscher, 1997), and now in the myxomycete $P$. polycephalum. We have previously reported that the replicatively active DNA polymerases $\alpha$ and $\delta$ were inhibited by PMLA (Fischer et al., 1989; Achhammer et al., 1995). That DNA polymerase $\varepsilon$ is also inhibited supports our assumption that PMLA forms 


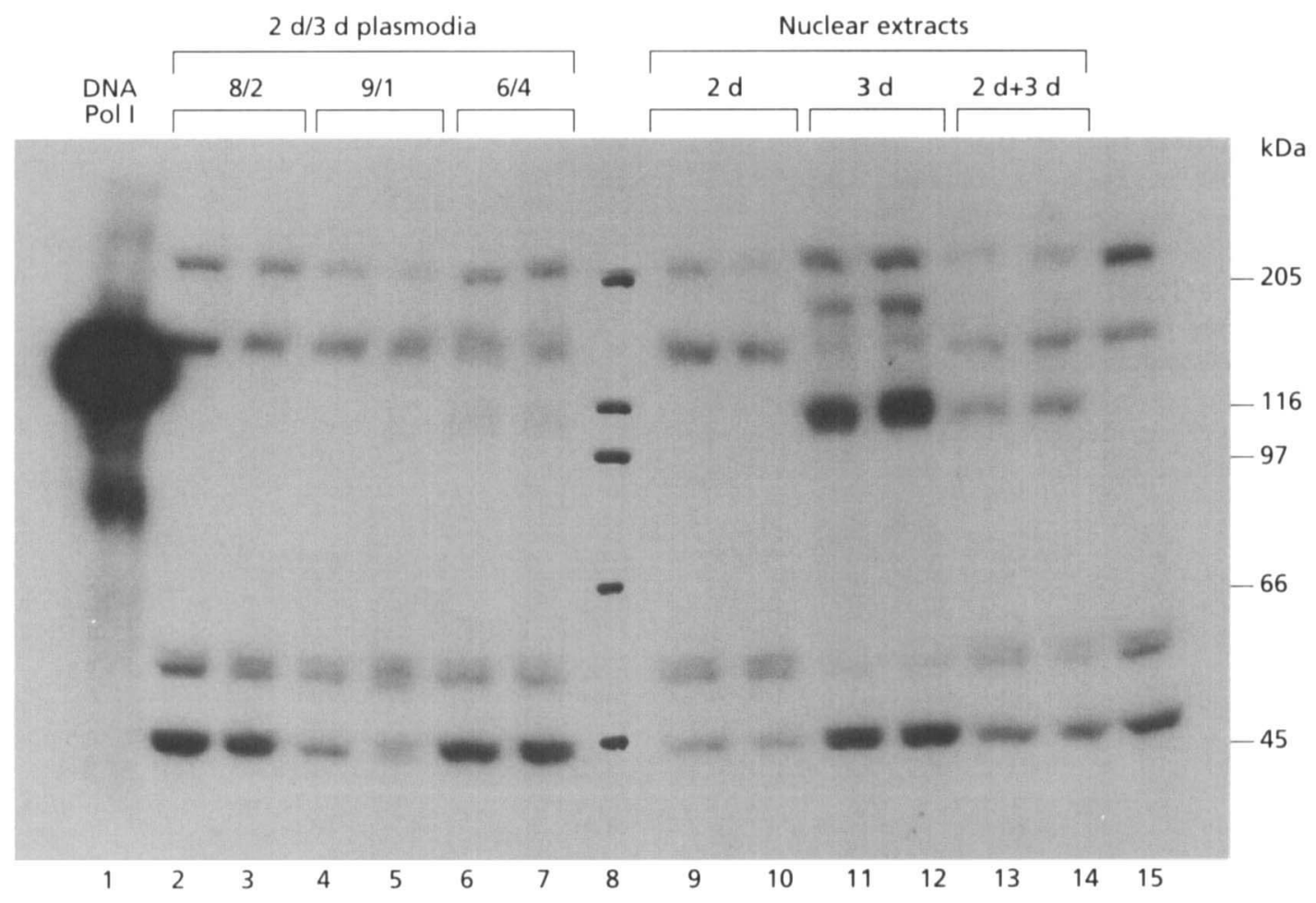

Fig. 8. Absence of artificial nicking demonstrated by cell mixing. Plasmodia ( 2 and $3 \mathrm{~d}$ old) were mixed at various ratios (mass/mass) before cell lysis. Nuclear extracts were prepared in the absence of Percoll. Labelling was performed according to the standard assay including AFBdCTP and SDS-PAGE (10\% acrylamide). Lane 1, 0.1 unit $E$. coli DNA polymerase 1 (control for indicating labelling); lanes 9 and 10, 2-d-old plasmodia; lanes 11 and 12, 3-d-old plasmodia; lanes 2-7, mixtures of 2- and 3-d-old plasmodia at the indicated mass ratio before lysis; lane 15, same as for lane 2, but twice the amount of extract; lanes 13 and 14, 1:1 (by vol.) mixture of the nuclear extracts from 2-d-old and 3-d-old plasmodia. Lane 8, molecular mass marker proteins.

complexes with replicatively active proteins. This is further substantiated by comparing DNA polymerases in purified samples and in nuclear extracts of plasmodia. Photoaffinity labelling revealed that several of the subunits of the holoenzymes were in a more 'open' configuration when they were purified than in the nuclear extract. Complex formation with PMLA rendered them inaccessible for the cross-linking DNA. Percoll partially disrupted the complexes by a mechanism still to be clarified. The induction of leakage of particular proteins from the nuclei is in support of the complex formation. The existence of PMLA-DNA polymerase-histone complexes in plasmodial nuclei, even in the presence of Percoll, has been demonstrated (Angerer \& Holler, 1995). Maintenance of the complexes could be the molecular basis for the reported PMLA homeostasis (Schmidt et al., 1996; Karl \& Holler, 1998).

The fate of DNA polymerases when DNA was no longer replicated was studied at the arrest of plasmodial proliferation before differentiation to spherules (a cell form of the organism starving in the dark) or spores (starving in the light). DNA polymerases were nicked, but as such were still active in the nuclear extract before they finally disappeared. Nicking could provoke functions specific for growth termination of plasmodia, such as prevention of the re-entry of protein-PMLA complexes when exported from the nucleus.

We find that $P$. polycephalum DNA polymerase $\alpha, \delta$, and $\varepsilon$ share similarities with the polymerases from higher eukaryotes. The results from immunostaining indicated conservation of epitopes in the case of the replication factors. The abundant $46 \mathrm{kDa}$ PCNA-like polypeptide and the $54 \mathrm{kDa} \mathrm{RP}-\mathrm{A}$-like species are novel because of their unusual sizes. The replication apparatus may thus be similar to that of animals, fungi and plants. Observed special features such as binding to PMLA may account for the plasmodium-specific physiology.

\section{ACKNOWLEDGEMENTS}

We are indebted to Drs M. I. Dobrikov and G. V. Shishkin for their encouragement, and to Dr Andrea Brückner for reading the manuscript. The work was funded by grants Ho 416/28-1 and 436 RUS-113/38 from the Deutsche Forschungsgemeinschaft, and by grants 96-04-50114 and 96-04-00133 from the Russian Fund for Basic Research. 


\section{REFERENCES}

Achhammer, G., Angerer, B., Windisch, C., Uhl, A. \& Holler, E. (1992). DNA polymerase $\alpha$-primase complex of Physarum polycephalum. Cell Biol Int Rep 16, 1047-1053.

Achhammer, G., Winkler, A., Angerer, B. \& Holler, E. (1995). DNA polymerase $\delta$ of Physarum polycephalum. Curr Genet 28, 534-545.

Angerer, B. \& Holler, E. (1995). Large complexes of PMLA with DNA polymerase- $\alpha$, histones, and other proteins in nuclei of growing plasmodia of Physarum polycephalum. Biochemistry 34, 14741-14751.

Baldauf, S. L. \& Doolittle, W. F. (1997). Origin and evolution of the slime molds (Mycetozoa). Proc Natl Acad Sci USA 94, 12007-12012.

Burland, T. G., Solnica-Krezel, L., Bailey, J., Cunningham, D. B. \& Dove, W. F. (1993). Patterns of inheritance, development and the mitotic cycle in the protist Physarum polycephalum. Adv Microb Physiol 35, 1-69.

Cavalier-Smith, T. (1993). Kingdom protozoa and its 18 phyla. Microbiol Rev 57, 953-994.

Chui, G. \& Linn, S. (1995). Further characterization of HeLa DNA polymerase $\varepsilon$. J Biol Chem 270, 7799-7808.

Cote, S. \& Palotta, D. (1985). Anomalous cleavage of histone H1 from Physarum polycephalum. Biochim Biophys Acta 828, 22-28.

Daniel, J. W. \& Baldwin, H. H. (1964). Methods of culture for plasmodial myxomycetes. Methods Cell Physiol 1, 9-13.

Doronin, S. V., Dobrikov, M. I. \& Lavrik, O. I. (1992). Photoaffinity labeling of DNA polymerase $\alpha$ DNA primase complex based on the catalytic competence of a $\mathrm{dNTP}$ reactive analog. FEBS Lett 313, 31-33.

Fischer, H., Erdmann, S. \& Holler, E. (1989). An unusual polyanion from Physarum polycephalum that inhibits homologous DNA polymerase $\alpha$ in vitro. Biochemistry 28, 5219-5226.

Garrison, P. N. \& Barnes, L. D. (1992). Determination of dinucleoside polyphosphates. In $A p_{4} A$ and Other Dinucleoside Polyphosphates, pp. 29-61. Edited by A. G. McLennan. Boca Raton, FL: CRC Press.

Gary, S. L. \& Burgers, P. M. (1995). Identification of the fifth subunit of Saccharomyces cerevisiae replication factor C. Nucleic Acids Res 23, 4986-4991.

Hindges, R. \& Hubscher, U. (1997). DNA Polymerase $\delta$, an essential enzyme for DNA transactions. Biol Chem Hoppe Seyler 378, 345-362.

Holler, E., Fischer, H., Weber, C., Stopper, H., Steger, H. \& Simek, H. (1987). A DNA polymerase with unusual properties from the slime mold Physarum polycephalum. Eur J Biochem 163, 397-405.

Holler, E., Angerer, B., Achhammer, G., Miller, S. \& Windisch, C. (1992a). Biological and biosynthetic properties of poly-L-malate. FEMS Microbiol Rev 103, 109-118.

Holler, E., Achhammer, G., Angerer, B. \& 9 other authors (1992b). Specific inhibition of Physarum polycephalum DNA polymerase $\alpha$-primase by poly(L-malate) and related polyanions. Eur $J$ Biochem 206, 1-6.

Hübscher, U., Maga, G. \& Podust, V. N. (1996). DNA replication accessory proteins. In DNA Replication in Eukaryotic Cells, pp. 525-543. Edited by M. L. DePamphilis. Cold Spring Harbor, NY: Cold Spring Harbor Laboratory.

Johansen, T., Johansen, S. \& Haugli, F. B. (1988). Nucleotide sequence of the Physarum polycephalum small subunit ribosomal
RNA as inferred from the gene sequence: secondary structure and evolutionary implications. Curr Genet 14, 265-273.

Karl, M. \& Holler, E. (1998). Multiple polypeptides immunologically related to PMLA hydrolase (polymalatase) in the plasmodium of the slime mold Physarum polycephalum. Eur $J$ Biochem 251, 405-412.

Kesti, T. \& Syvaoja, J. E. (1991). Identification and tryptic cleavage of the catalytic core of HeLa and calf thymus DNA polymerase epsilon. J Biol Chem 266, 6336-6341.

Laemmli, U. K. (1970). Cleavage of structural proteins during the assembly of the head of bacteriophage T4. Nature 227, 680-685.

Lavrik, O. I. \& Potapova, I. A. (1994). Affinity labeling of DNA polymerases. In Chemical Modification of Enzymes, pp. 219-307. Edited by B. I. Kurganov, N. K. Nagradova \& O. I. Lavrik. Moscow: Nova Science.

Lavrik, O. I., Prasad, R., Beard, W. A., Safronov, I. V., Dobrikov, M. I., Srivastava, D. K., Shishkin, G. V., Wood, T. G. \& Wilson, S. H. (1996). dNTP binding to HIV-1 reverse transcriptase and mammalian DNA polymerase $\beta$ as revealed by affinity labeling with a photoreactive dNTP analog. J Biol Chem 271, 21891-21897.

Lavrik, O. I., Nasheuer, H.-P., Weisshart, K., Wold, M. S., Prasad, R., Beard, W., Wilson, S. \& Favre, A. (1998). Subunits of human replication protein $A$ are crosslinked by photoreactive primers synthesized by DNA polymerases. Nucleic Acids Res 26, 602-607.

Margulis, L. \& Schwartz, K. V. (1982). Five Kingdoms: an Illustrated Guide to the Phyla of Life on Earth. San Francisco: W. H. Freeman.

Mitina, R. L., Mustev, A. A., Zaychikov, E. F., Khomov, V. V. \& Lavrik, O. I. (1990). Highly selective affinity labeling of the primerbinding site of Escherichia coli DNA polymerase I. FEBS Lett 272, 181-183.

Nasheuer, H.-P., von Winkler, D., Schneider, C., Dornreiter, I., Gilbert, I. \& Fanning, E. (1992). Purification and functional characterization of bovine RP-A in an in vitro SV40 DNA replication system. Chromosoma 102, S52-S59.

Remy, P. (1992). Intracellular functions of $A p_{n} N$ : eukaryotes. In $A p_{4} A$ and Other Dinucleoside Polyphosphates, pp. 151-204. Edited by A. G. McLennan. Boca Raton, FL: CRC Press.

Safronov, I. V., Sherbick, N. V., Khodyreva, S. N., Wlassoff, W. A., Dobrikov, M. I., Shishkin, G. V. \& Lavrik, O. I. (1997). New photoreactive N4-substituted dCTP analogues: preparation, photochemical characteristics, and substrate properties in HIV-1 reverse transcriptase-catalyzed DNA synthesis. Russ J Bioorg Chem 23, 576-585.

Sambrook, I., Fritsch, E. F. \& Maniatis, T. (1989). Molecular Cloning: a Laboratory Manual, 2nd edn. Cold Spring Harbor, NY: Cold Spring Harbor Laboratory.

Schmidt, A., Windisch, C. \& Holler, E. (1996). Nuclear accumulation and homeostasis of the unusual polymer PMLA in plasmodia of Physarum polycephalum. Eur J Cell Biol 70, 373-380.

Sugimoto, K., Sakamoto, Y., Takahashi, O. \& Matsumoto, K. (1995). HYS2, an essential gene required for DNA replication in Saccharomyces cerevisiae. Nucleic Acids Res 23, 3493-3500.

Sugino, A. (1995). Yeast DNA polymerases and their role at the replication fork. Trends Biochem Sci 20, 319-323.

Towbin, H., Staehelin, T. \& Gordon, J. (1979). Electrophoretic transfer of proteins from polyacrylamide gels to nitrocellulose sheets : procedure and some applications. Proc Natl Acad Sci USA 76, 4350-4354.

Uitto, L., Halleen, J., Hentunen, Z., Hoyhtya, M. \& Syvaojy, E. 
(1995). Structural relationship between DNA polymerase epsilon and epsilon* and their occurrence in eukaryotic cells. Nucleic Acids Res 23, 244-247.

Weber, C., Fischer, H. \& Holler, E. (1988). Purification and characterization of DNA polymerase $\alpha$ from Physarum polycephalum. Eur J Biochem 176, 199-206.

Wold, M. S. (1997). Replication protein A : a heterotrimeric, single stranded DNA-binding protein required for eukaryotic DNA metabolism. Annu Rev Biochem 66, 61-92.
Woese, C. R. (1994). There must be a prokaryote somewhere: microbiology's search for itself. Microbiol Rev 58, 1-9.

Zhang, J., Tan, C. K., McMullen, B., Downey, K. M. \& So, A. G. (1995). Cloning of the cDNAs for the small subunits of bovine and human DNA polymerase $\delta$ and chromosomal location of the human gene. Genomics 29, 179-186.

Received 23 February 1998; revised 9 July 1998; accepted 15 July 1998. 